\title{
13. PETROGRAPHY OF LATE ALBIAN PLATFORM-INTERIOR FACIES STRATA: LEG 101, SITE 627, LITTLE BAHAMA BANK ${ }^{1}$
}

\author{
R. P. Freeman-Lynde ${ }^{2}$
}

\begin{abstract}
Late Albian dolostone, dolomitic limestone, gypsiferous limestone, and gypsiferous dolomitic limestone recovered at Site 627 record deposition principally in lagoons and on tidal flats, generally under low-energy, highly restricted conditions. The section penetrated is dominated by lagoonal lithofacies, which make up two-thirds of the samples examined, while peritidal lithofacies rocks compose only one-third of the examined samples. Round molds of miliolid foraminifers and elongate molds of mollusk grains are abundant in lagoonal lithofacies rocks and common in peritidal lithofacies samples. Compaction effects, which apparently formed during shallow burial, as evidenced by abundant flattened burrows and intraclasts and only rare breakage and close packing of skeletal grains in packstones, are common.

The section appears to consist of a series of upward-shoaling sequences about $5 \mathrm{~m}$ thick separated by sharp contacts, with lagoonal lithofacies grading upward to peritidal lithofacies. Dolomite occurs as both dolomicrite and generally fine, idiotopic crystals. Dolomicrite is confined principally to the upper $28 \mathrm{~m}$ of the section. Fine, idiotopic dolomite crystals are distributed throughout the section. Although dolomite rhombs generally are fine crystalline $(25-50$ $\mu \mathrm{m}$ ), very fine $(10-15 \mu \mathrm{m}$ ) and medium (maximum $150 \mu \mathrm{m}$ ) dolomite crystals occur in about two-thirds of the samples examined. Dolomite crystals either are clear or have cloudy centers and clear rims. The size of the dolomite crystals appears to correlate with lithofacies within individual upward-shoaling sequences, although the reason for this relationship is unclear. Dolomitization appears to have occurred during early diagenesis by both hypersaline brines and fluids derived from mixing of marine and meteoric water.
\end{abstract}

\section{INTRODUCTION}

Leg 101, Site 627, of the Ocean Drilling Program is located on the Blake Plateau north of Little Bahama Bank at a depth of $1028 \mathrm{~m}$ (Fig. 1). Drilling at Hole 627B penetrated late Albian bank-interior facies dolostone, limestone, and gypsum of the middle $^{3}$ and Early Cretaceous megabank ${ }^{4}$ from 476 to 536 meters below the seafloor (mbsf) (Fig. 2). Cenomanian marls overlying bank-interior rocks contain middle/outer shelf to upper bathyal benthic foraminifers and indicate drowning of the megabank at Site 627 in middle Cretaceous time (Austin, Schlager, et al., 1986). Middle Cretaceous megabank strata were not reached at any other site occupied during Leg 101, although Albian deep-water deposits were penetrated at Site 635 in Northeast Providence Channel. If the megabank does underlie this channel, then these Albian deep-water deposits indicate that drowning of the megabank was diachronous (Austin, Schlager, et al., 1986).

Megabank carbonates of middle and Early Cretaceous age were recovered at several other places in the Bahamas and the Blake Plateau, although sampling was concentrated on the precipitous Blake-Bahama Escarpment, where megabank strata crop out at depths greater than $2000 \mathrm{~m}$ because of the erosional retreat of the slope (Heezen and Sheridan, 1966; Sheridan et al.,

\footnotetext{
${ }^{1}$ Austin, J. A., Jr., Schlager, W., et al., 1988. Proc. ODP, Sci. Results, 101: College Station, TX (Ocean Drilling Program).

2 Department of Geology, University of Georgia, Athens, GA 30602.

3 Barremian to Cenomanian inclusive, as used here.

4 Buried shallow-water carbonate bank postulated by Paulus (1972), Schlager and Ginsburg (1981), and Sheridan et al. (1981) to underlie both deep-water basins and shallow-water banks in the modern Bahamas and to be exposed on the Blake-Bahama and Florida Escarpments and in eastern Mexico (Bryant et al., 1969; Griffith et al., 1969; Enos, 1974; Freeman-Lynde et al., 1981; FreemanLynde, 1983). This paper does not consider the large-scale question of whether the proposed megabank underlies deep-water basins.
}

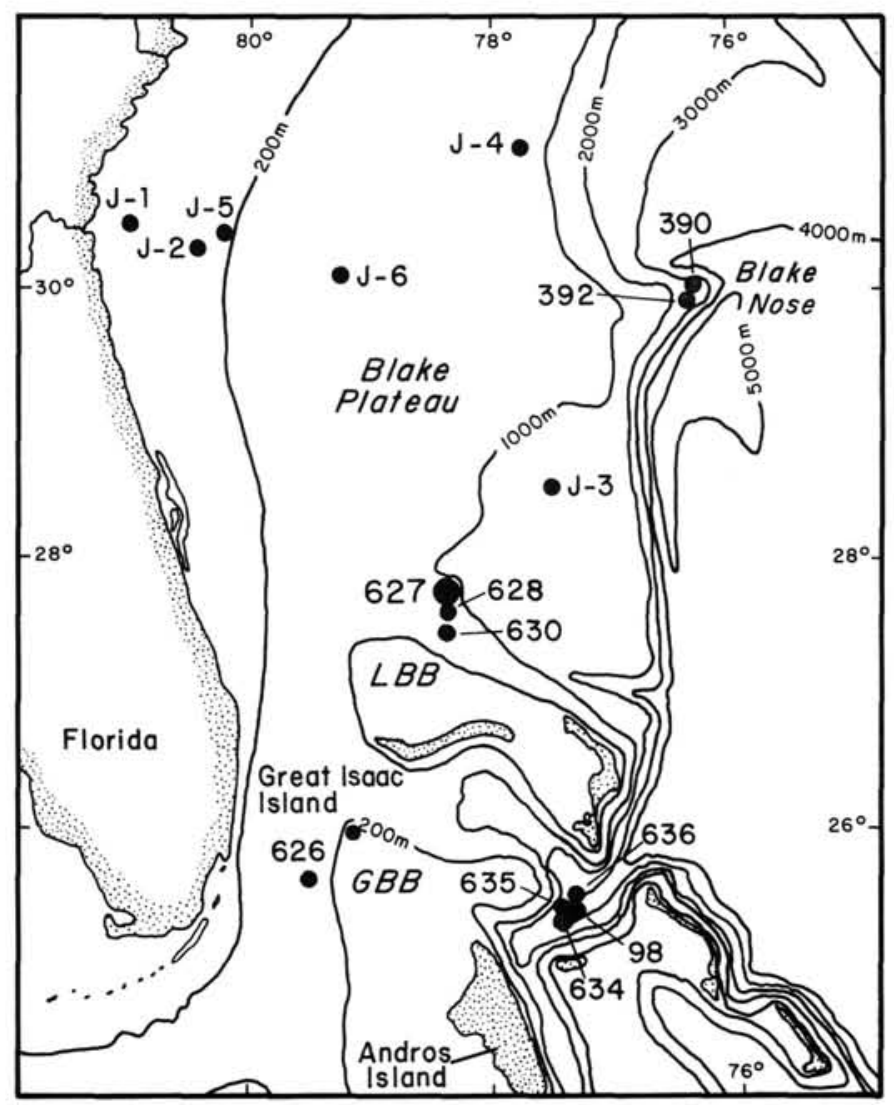

Figure 1. Map of northwestern Bahamas and Blake Plateau showing location of JOIDES, DSDP, and ODP sites, including ODP Site 627 (after Van Buren and Mullins, 1983). 


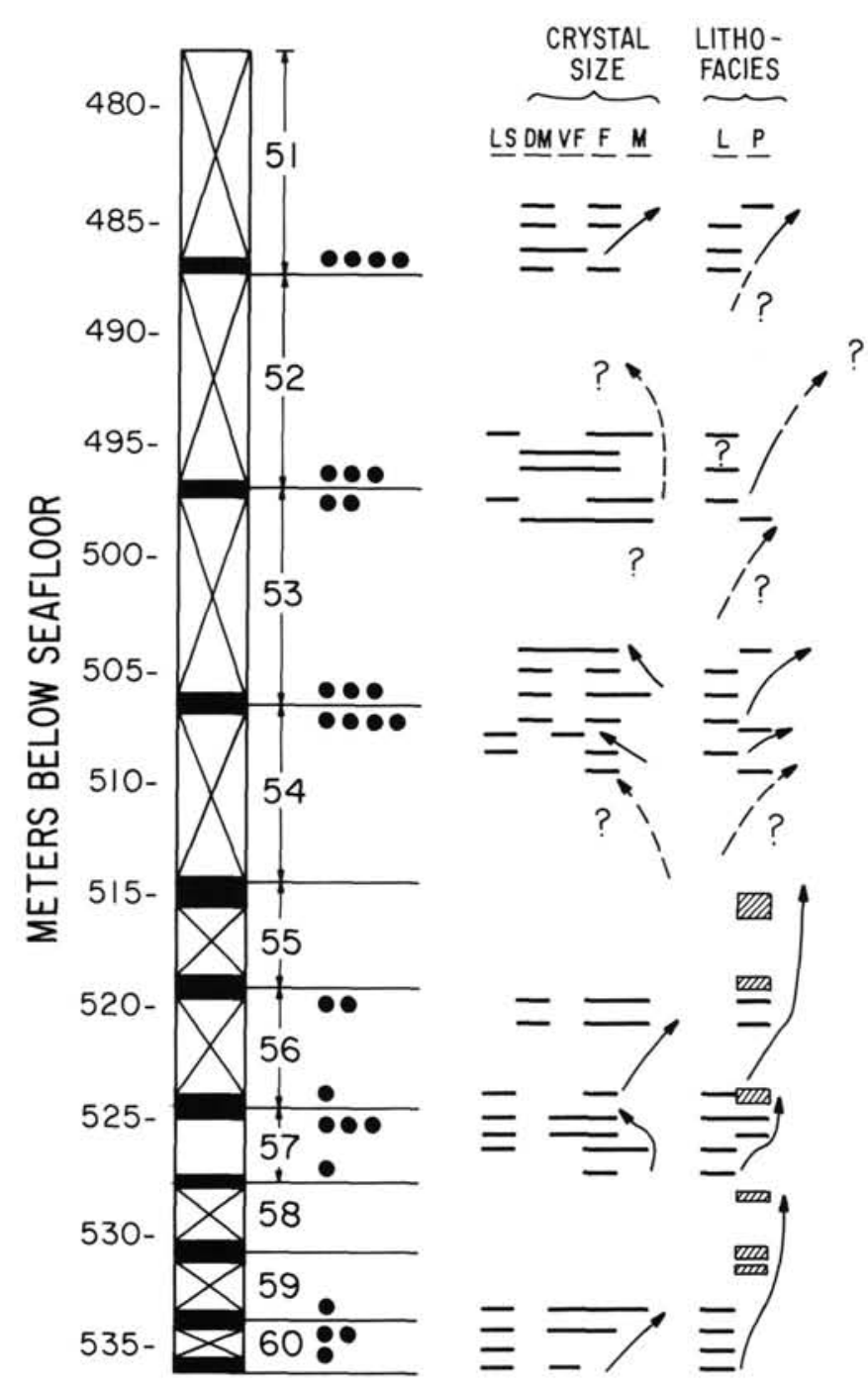

Figure 2. Summary of late Albian bank-interior section penetrated at Site 627. Core numbers are indicated. Recovered intervals are shown in black; nonrecovered intervals are marked by large $X$ pattern. Note the poor recovery. Positions of samples studied are shown by black dots adjacent to column. Occurrence of limestone (ls), size of dolomite crystals, and type of lithofacies (lagoonal or peritidal) shown at right. Gypsum is shown by rectangles with cross-hatching in the peritidal column. Arrows indicate upward-shoaling sequences and trends in size of dolomite crystals.

1969, 1971; Paull and Dillon, 1980, 1981; Freeman-Lynde et al., 1981; Corso, 1983; Freeman-Lynde and Ryan, 1985). Megabank rocks of middle and Early Cretaceous age exposed on the Blake-Bahama Escarpment consist mostly of peritidal and lagoonal limestone. Peritidal and lagoonal dolostone and patchreef/backreef limestone are subordinate in the section exposed on the escarpment. Barremian, or older, shallow-water limestones also were encountered from about 100 to $350 \mathrm{mbsf}$ at a water depth of $2600 \mathrm{~m}$ on Blake Nose during DSDP Leg 44 (Benson, Sheridan, et al., 1978). Overlying nannofossil chalk indicates drowning of Blake Nose in the Barremian, and again shows diachronous drowning of the megabank, with earlier drowning near the bank margin. Neocomian chalk recovered from Samana Embayment also shows early drowning of the megabank at bank-margin reentrants, or perhaps indicates that shallowwater conditions never prevailed here (Schlager et al., 1984).
Penetration of the megabank in the interior of the Bahama Platform and Blake Plateau was limited to four petroleum-company stratigraphic test wells (one each at Andros, Long, and Great Isaac islands on Great Bahama Bank, and one on Cay Sal Bank), as well as ODP Site 627 north of Little Bahama Bank (Spencer, 1967; Khudoley, 1967; Goodell and Garman, 1969; Meyerhoff and Hatten, 1974; Tator and Hatfield, 1975; Austin, Schlager, et al., 1986). The middle and Early Cretaceous section encountered in these wells consists of interbedded dolostone, limestone, and evaporite (mostly gypsum and anhydrite), although detailed lithologic descriptions have been published only for the sections drilled at Andros Island (Spencer, 1967; Goodell and Garman, 1969) and Site 627 (Austin, Schlager, et al., 1986). Nevertheless, abundant dolostone and evaporite in these wells contrast with the dominantly limestone sequence underlying the Blake-Bahama Escarpment. The top of the megabank varies in depth from about $1500 \mathrm{~m}$ at Site 627 to more than $3000 \mathrm{~m}$ at Andros Island.

\section{METHODS}

This paper presents detailed lithologic descriptions of the interbedded dolostone, dolomitic limestone, gypsiferous limestone, and gypsiferous dolomitic limestone recovered at Site 627 (Fig. 2). This analysis is based on the examination of 27 hand samples (Table 1) for sedimentary structures (mostly thin-section chips $3 \times 5 \mathrm{~cm}$ ) and on thin sections for petrographic features (for example, size of dolomite crystals), using standard research binocular stereo and petrographic microscopes (Figs. 3 through 9). Calcite was distinguished from dolomite by staining with Alizarin red-S. Distances between samples within continuous sections of cores ranged from 0 to $47 \mathrm{~cm}$. Nearly all sections and core catchers were sampled, with the exception of those recovering only gypsum or very small pieces. Such data generally allow fairly conclusive interpretation of environments of deposition and place limits on possible dolomitization mechanisms and diagenetic histories for this section. To firmly establish the diagenetic history of the carbonate section recovered at Site 627 , however, geochemical study of these rocks, including determination of their stable oxygen, carbon, and strontium isotopic compositions, will be necessary.

\section{ENVIRONMENTS OF DEPOSITION}

Like most middle and Early Cretaceous rocks exposed on the Blake-Bahama Escarpment and drilled on Great Bahama and Cay Sal banks, dolostone, dolomitic limestone, gypsiferous limestone, and gypsiferous dolomitic limestone recovered at Site 627 record deposition principally in lagoons and on tidal flats, generally under low-energy, highly restricted conditions.

\section{Lagoonal Lithofacies}

The section penetrated at Site 627 is dominated by lagoonal lithofacies rocks, which make up two-thirds (18 of 27) of the

Table 1. Site 627 samples examined in this study.

\begin{tabular}{cc}
\hline Sample/interval (cm) & Sample/interval (cm) \\
\hline${ }^{\mathrm{a}}$ 101-627B-51X, CC, 0-3 & 101-627B-54X-1, 32-37 \\
627B-51X, CC, 7-9 & $627 \mathrm{~B}-54 \mathrm{X}-1,38-42$ \\
627B-51X, CC, 24-25 & $627 \mathrm{~B}-56 \mathrm{X}-1,7-8$ \\
627B-51X, CC, 31-33 & $627 \mathrm{~B}-56 \mathrm{X}-1,10-14$ \\
627B-52X, CC, 5-7 & $627 \mathrm{~B}-56 \mathrm{X}, \mathrm{CC}, 42-49$ \\
627B-52X, CC, 9-12 & $627 \mathrm{~B}-57 \mathrm{X}-1,7-13$ \\
627B-52X, CC, 28-29 & $627 \mathrm{~B}-57 \mathrm{X}-1,16-19$ \\
$\mathrm{a} 627 \mathrm{~B}-53 \mathrm{X}-1,12-14$ & $627 \mathrm{~B}-57 \mathrm{X}-1,66-68$ \\
627B-53X-1, 18-23 & $627 \mathrm{~B}-57 \mathrm{X}, \mathrm{CC}, 37-40$ \\
627B-53X, CC, 8-11 & ${ }^{a} 627 \mathrm{~B}-59 \mathrm{X}, \mathrm{CC}, 5-8$ \\
627B-53X, CC, 13-17 & $627 \mathrm{~B}-60 \mathrm{X}-1,35-37$ \\
627B-53X, CC, 26-32 & $627 \mathrm{~B}-60 \mathrm{X}-1,37-40$ \\
627B-54X-1, 0-6 & ${ }^{2} 627 \mathrm{~B}-60 \mathrm{X}, \mathrm{CC}, 26-32$ \\
627B-54X-1, 17-23 & \\
\hline
\end{tabular}

${ }^{a}$ Duplicate thin sections examined. 


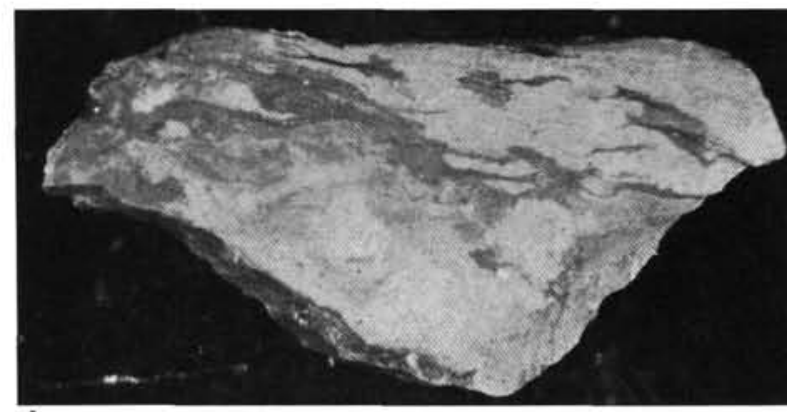

A


D
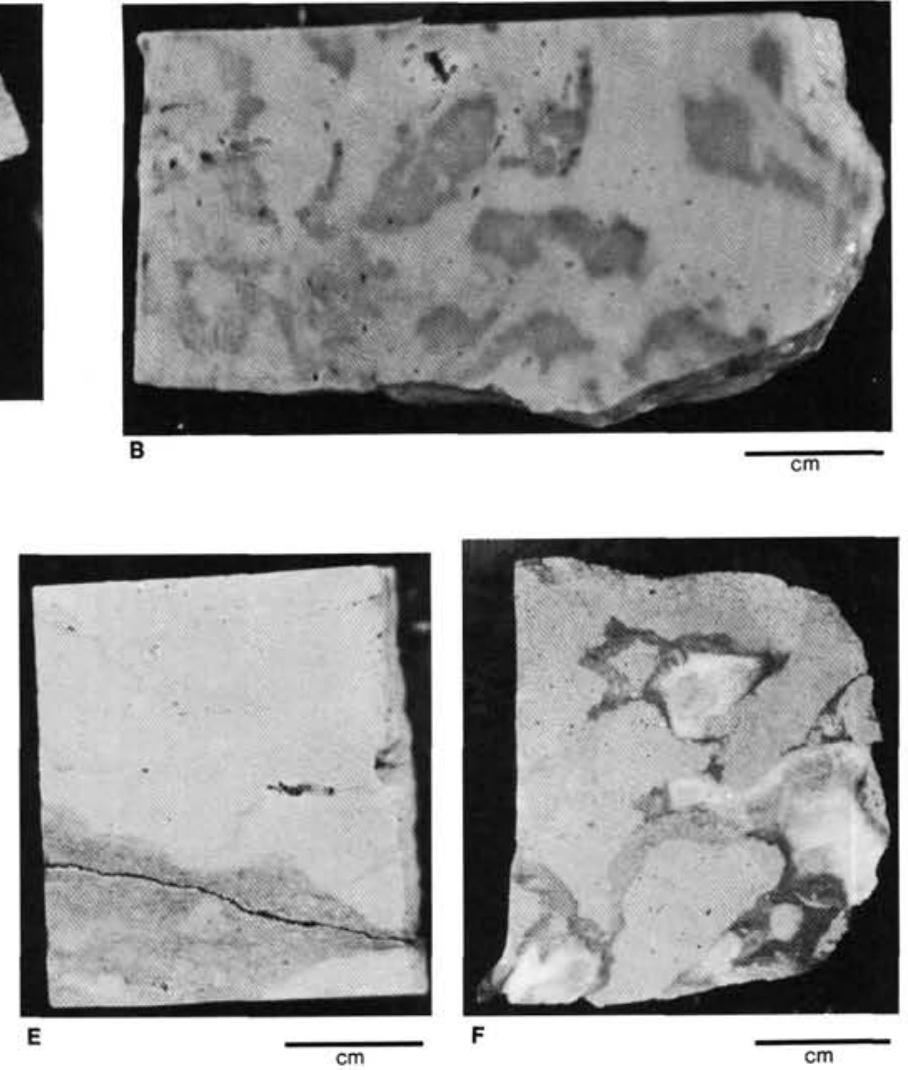

Figure 3. Photographs of thin-section chips illustrating sedimentary structures characteristic of lagoonal lithofacies. A. Flattened burrows in wackestone and packstone of Sample 101-627B-60X-1, 35-37 cm. B. Undeformed burrows in moldic mudstone and wackestone of Sample 101-627B-56X-CC, 42-49 cm. Up is to the right. C. Intraclastic dolostone with wackestone texture of Sample 101-627B-51X, CC, 24-25 cm. Note geopetal structure at center left. D. Flattened burrows in moldic dolostone with wackestone and packstone texture of Sample 101-627B$53 \mathrm{X}, \mathrm{CC}, 26-32 \mathrm{~cm}$. E. Large burrow filled with lagoonal intraclastic wackestone and packstone sediments in peritidal fenestral mudstone and wackestone of Sample 101-627B-57X-1, 7-13 cm. F. Sample 101-627B-60X-1, 37-40 cm, showing disruption of moldic wackestone and packstone by gypsum nodules.

samples examined in this study (Fig. 2). Specimens exhibiting extensive burrowing, mottling, or bioturbation in hand samples (Fig. 3) or having abundant skeletal grains in thin sections (Figs. 4 through 6) are interpreted to have been deposited in lagoons or subtidal ponds. Mudstone and wackestone textures in combination with a restricted fauna of miliolid foraminifers, ostracodes, and mollusk grains (Figs. 3 and 4), which suggest deposition under low-energy, highly restricted conditions, occur in 15 of 18 lagoonal lithofacies samples. On the other hand, packstone texture combined with uniform orientation or graded bedding of stenohaline (echinoids, Inoceramus) skeletal grains (Figs. 5 through 7), which indicate higher energy, less restricted conditions at the site of deposition, occur in only 3 of 18 lagoonal lithofacies samples. These higher energy, less restricted conditions probably resulted from deposition during storms or in channels.

Round molds of miliolid foraminifers and elongate molds of mollusk grains (Figs. 3 and 4) are abundant in lagoonal lithofacies rocks deposited under low-energy, highly restricted conditions ( 12 of 15 samples) but are rare in those rocks deposited under higher energy, less restricted conditions (Figs. 5 and 6). In samples from Core 101-627B-60X, molds are partly filled with gypsum (Fig. 4).

About $40 \%$ (7 of 18) of the lagoonal lithofacies samples show compaction effects, which apparently formed during shallow burial, as evidenced by abundant flattened burrows and intraclasts (Fig. 3), and only rare breakage and close packing of skeletal grains in packstones (Fig. 6). Compaction of burrows and intraclasts in low-energy, highly restricted lagoonal rocks as well as uniform grain orientation and graded bedding in higher energy, less restricted lagoonal samples results in a laminated appearance of such specimens (Figs. 3 and 5 through 8). Such lamination differs from that typifying peritidal lithofacies samples, as discussed next (Figs. 4 and 7 through 8).

Intraclasts occurring in lagoonal rocks generally result from bioturbation, although those in Sample 101-627B-60X-1, 37-40 $\mathrm{cm}$, formed as a result of gypsum nodule growth (Fig. 3).

\section{Peritidal Lithofacies}

Peritidal lithofacies rocks compose only one-third (9 of 27) of the samples examined (Fig. 2). Note that one of these samples (101-627B-57X-1, 7-13 cm) also contains burrows and is included as one of the samples interpreted as lagoonal (Figs. 2 and 3). Interpretation of deposition on tidal flats is based on occurrence of algal lamination, teepee structures, or possible fenestral porosity in hand samples and thin sections (Figs. 3 and 4,7 and 8 ). Mudstone and wackestone textures and sparse miliolid foraminifers, ostracodes, and mollusk grains in thin sections indicate the low-energy, restricted conditions at the site of deposition (Fig. 7).

Round molds of miliolid foraminifers and elongate molds of mollusk grains (Figs. 4 and 7) are common but not abundant in peritidal lithofacies samples. About 55\% (5 of 9) of peritidal samples show compaction effects (Figs. 7 and 8). Although enhancing their laminated appearance, compaction is not the cause of lamination in peritidal samples, as it is for lagoonal samples. 


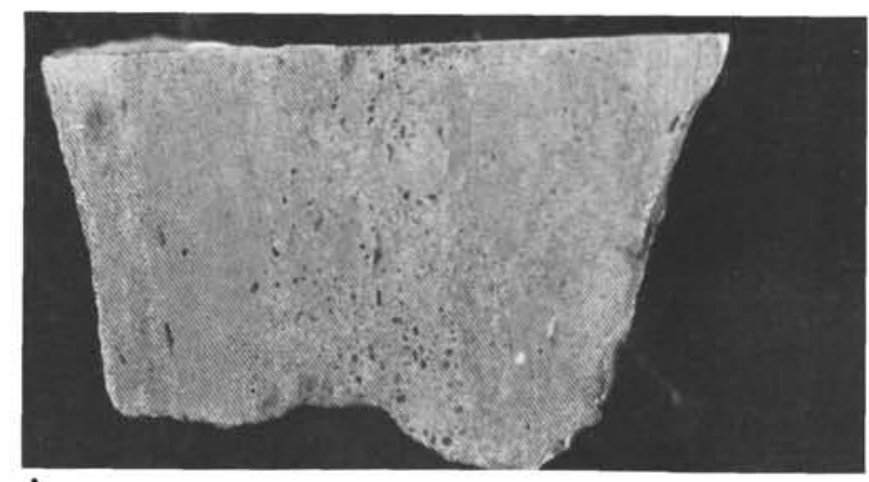

A

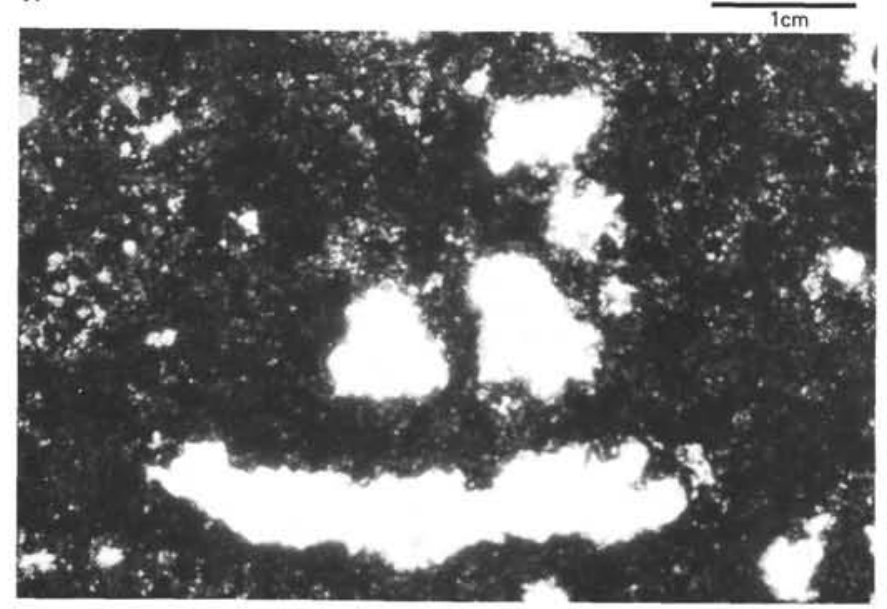

C

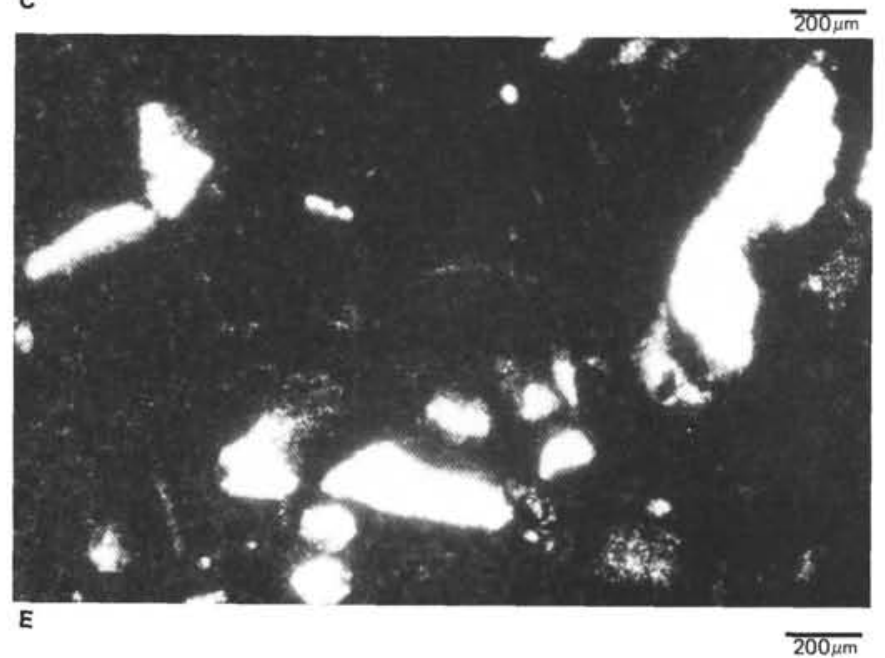

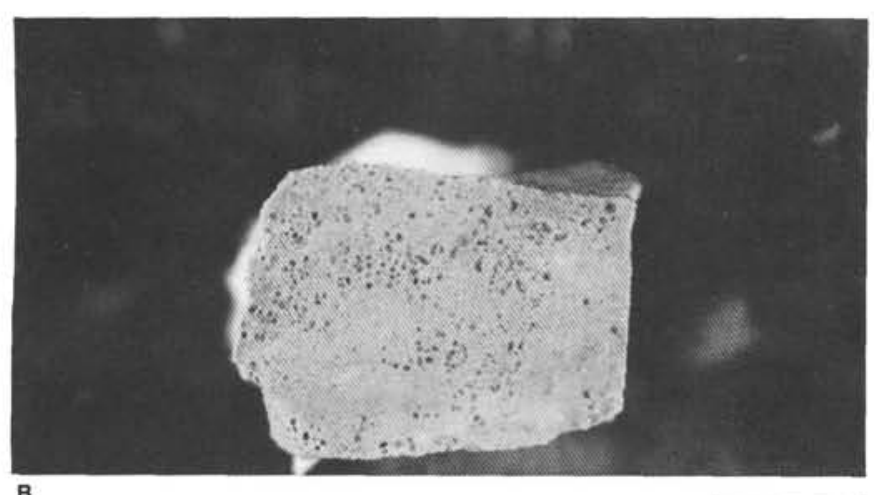
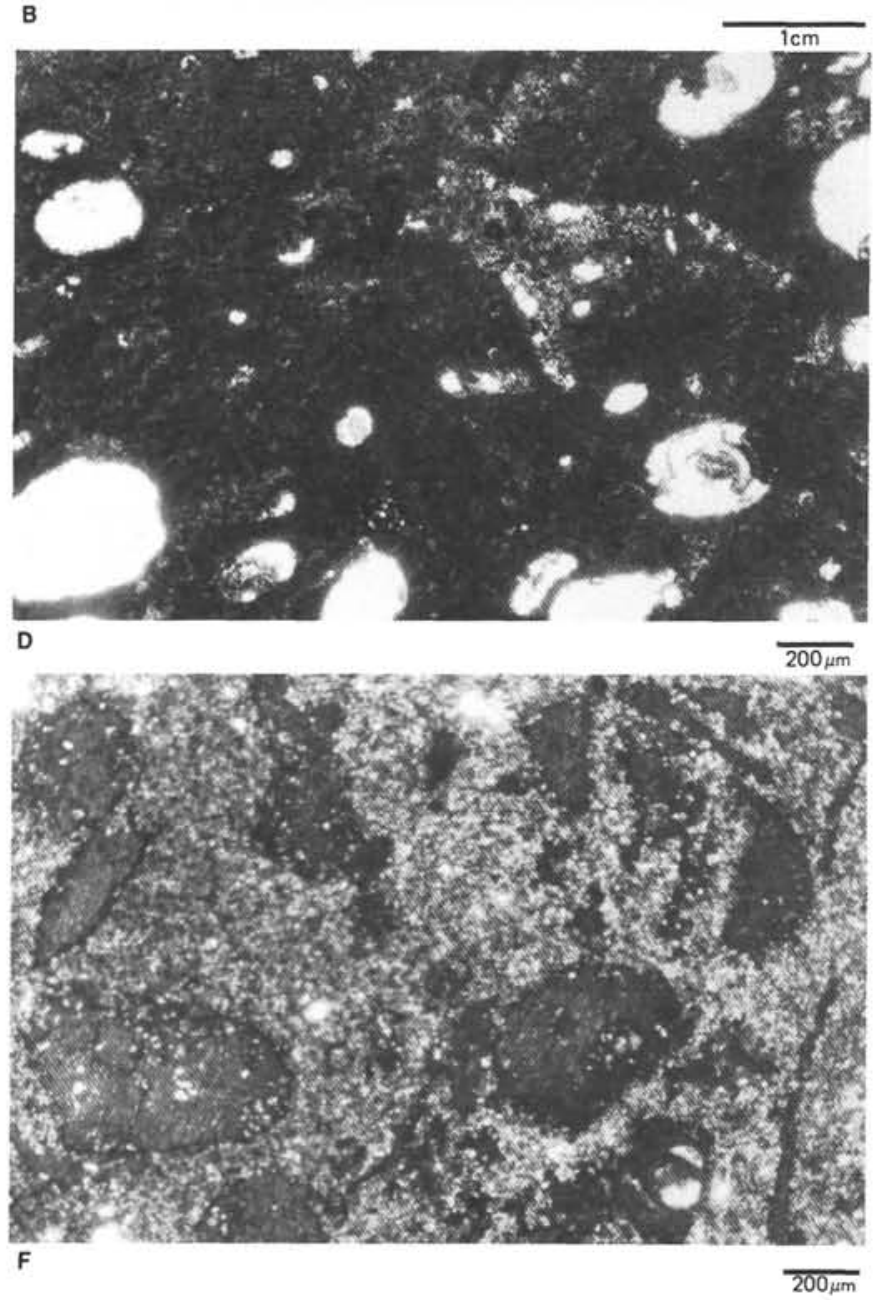

Figure 4. Photographs of thin-section chips (A and B) and thin-section photomicrographs (C-F) illustrating moldic porosity in lagoonal and peritidal lithofacies. Thin-section photomicrographs taken with plain light. A. Laminated peritidal dolostone, Sample 101-627B-53X, CC, 8-11 cm, containing alternating laminae of slightly moldic mudstone and highly moldic packstone and wackestone. B. Burrowed lagoonal wackestone and packstone, Sample 101-627B-59X, CC, 5-8 cm, with moldic packstone sediment filling burrows in wackestone. C. Elongate and round molds after mollusk grains and miliolid foraminifers in lagoonal dolostone, Sample 101-627B-51X, CC, 7-9 cm, having wackestone texture. Fine, idiotopic-P dolomite crystals are scattered throughout dolomicrite matrix with clotted appearance. D. Round molds after miliolid foraminifers (one is still visible at lower right) in laminated peritidal wackestone of Sample 101-627B-54X-1, 17-23 cm. Note probable algal skeletal fragment at upper right. E. Elongate molds after mollusk skeletal grains in lagoonal wackestone of Sample 101-627B-60X, CC, 26-32 cm. F. Gypsum-filled molds (both elongate and round after mollusk skeletal grains and miliolid foraminifers) in lagoonal wackestone of Sample 101-627B-60X, CC, 26-32 cm. Micrite matrix has been replaced by fine, idiotopic-E dolomite crystals.

\section{Upward-Shoaling Sequences}

Most of the nongypsum section recovered at Site 627 occurs as rock fragments no more than $10 \mathrm{~cm}$ long (Austin, Schlager, et al., 1986), and thus the nature of contacts and the relationships between lagoonal and peritidal lithofacies are difficult to estab- lish. However, a 42-cm-long continuous core recovered in Section 101-627B-54X-1 (Fig. 8), particularly the interval from 36 to $39 \mathrm{~cm}$, clearly shows that contacts between lagoonal and underlying peritidal lithofacies are sharp and that lagoonal lithofacies grade upward to overlying peritidal lithofacies. Taken to- 


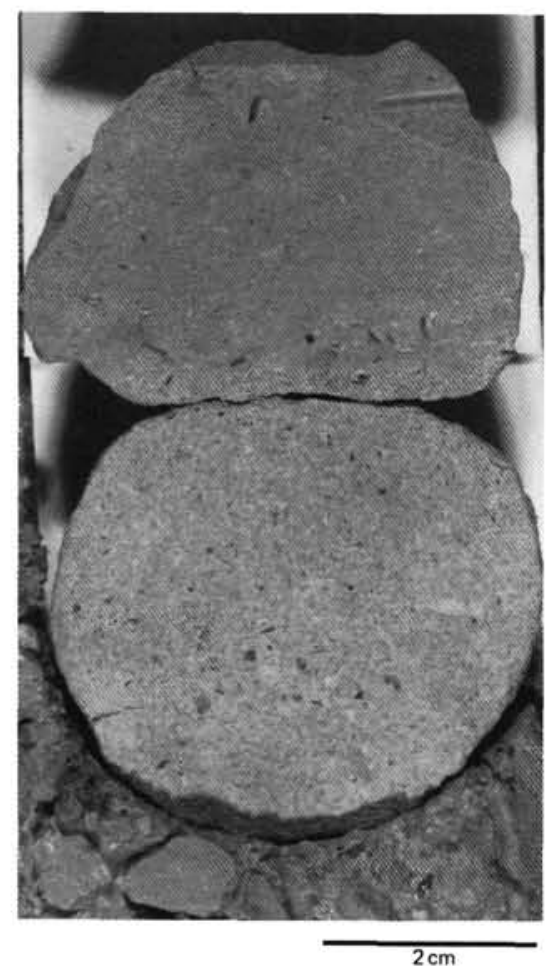

Figure 5. Photograph of rock fragments at the top of Section 101-627B$52 \mathrm{X}, \mathrm{CC}$, showing laminated fossiliferous packstone and wackestone recording deposition under higher energy, less restricted conditions than exhibited by other lagoonal lithofacies samples.

gether, a lagoonal interval and the overlying peritidal interval make up an upward-shoaling sequence.

Specifically, the interval from the base of Section 101-627B$54 \mathrm{X}-1$ to $38-39 \mathrm{~cm}$ is laminated and interpreted as peritidal. A sharp boundary separates this dark, oil-impregnated interval from a light, bioturbated interval from $38-39$ to $27 \mathrm{~cm}$, which is interpreted as lagoonal. Although the contact between these two lithofacies is sharp, burrows filled with light lagoonal sediment extend down into the peritidal interval. This lagoonal interval grades up to a second peritidal interval from 27 to $22 \mathrm{~cm}$, which is recognized by a teepee structure. This structure forms a sharp contact with a second overlying lagoonal interval from $22 \mathrm{~cm}$ to the top of the core. Again, abundant bioturbation characterizes this second lagoonal unit.

Sample 101-627B-57X-1, 7-13 cm, also provides information about the nature of contacts and relationships between lagoonal and peritidal lithofacies, as it contains both lagoonal and peritidal intervals (Fig. 3). Again, the contact between lithofacies is sharp, although lagoonal sediment appears to occur within a burrow. The peritidal interval is recognized by algal lamination and possible fenestral porosity.

The entire 50-m section of bank-interior facies strata, including supratidal gypsum, recovered at Site 627 seems to consist of at least nine upward-shoaling sequences (Fig. 2). This conclusion is reasonably well constrained for the lower $22 \mathrm{~m}$ of the section (Cores 101-627B-55X through 101-627B-60X), that is, the gypsiferous portion of the sequence, where recovery rates were better. It appears that the dolostone samples examined for this study, combined with sections containing mostly gypsum (which were not examined), define three upward-shoaling sequences, assuming that unrecovered intervals consist of supratidal gypsum (Fig. 2). The thickness of each sequence ranges from 3 to $10 \mathrm{~m}$.

The number of upward-shoaling sequences that make up the upper $28 \mathrm{~m}$ of the section (Cores 101-627B-51X through 101-
627B-54X) is poorly constrained because of nonrecovery of most of the section. At least six upward-shoaling sequences are required (Fig. 2). Thicknesses of each sequence range from 16-17 $\mathrm{cm}$ (that in Section 101-627B-54X-1, described above) to about $10 \mathrm{~m}$, assuming that unrecovered intervals contain only the missing parts of the sequences defined by samples (Fig. 2).

\section{DOLOMITE CHARACTERISTICS}

Dolomite occurs both as dolomicrite and as fine, idiotopic (Gregg and Sibley, 1984) rhombs in the samples examined (Figs. 2 and 9). Dolomicrite is most common in samples from the upper $28 \mathrm{~m}$ of the section (Cores 101-627B-51X through 101-627B$54 \mathrm{X}$ ), and occurs only twice (two samples from Section 101$627 \mathrm{~B}-56 \mathrm{X}-1$ ) in samples from the lower $22 \mathrm{~m}$ of the section (Cores 101-627B-55X through 101-627B-60X).

On the other hand, fine, idiotopic dolomite rhombs occur throughout the section ( 26 of 27 samples). Although rhombs are generally fine crystalline $(25-50 \mu \mathrm{m})$, very fine $(10-15 \mu \mathrm{m})$ and medium (maximum $150 \mu \mathrm{m}$ ), dolomite crystals occur in about two-thirds of the samples examined (Fig. 2). The coarsest crystals occur as linings in molds (idiotopic-C) (Figs. 4 and 6). Some samples have only a few fine crystals scattered in a micrite or dolomicrite matrix (idiotopic-P) (Figs. 4, 6 and 7, 9); other samples have lamellae consisting of almost $100 \%$ fine-crystalline rhombs (idiotopic-E and idiotopic-S) alternating with micrite or dolomicrite layers (Figs. 6 and 7); and other samples consist of almost $100 \%$ fine crystals (idiotopic-E and idiotopic-S), with only thin seams of micrite or dolomicrite between crystals (Figs. 7 and 9). Dolomite rhombs are clear (Figs. 4, 6 and 7, 9), although a few samples contain rhombs with cloudy centers and clear rims (Fig. 6). Most dolostone samples are porous owing to significant porosity between dolomite rhombs (Fig. 7) as well as to numerous molds (Figs. 4 and 7).

The size of the dolomite crystals appears to correlate with lithofacies within individual upward-shoaling sequences (Fig. 2). In those sequences of the upper $28 \mathrm{~m}$ of the section (Cores 101627B-51X through 101-627B-54X) that do not culminate with supratidal gypsum, maximum rhomb size occurs in lagoonal lithofacies rocks, and rhomb size decreases upward to a minimum in peritidal lithofacies samples. In contrast, sequences of the lower $22 \mathrm{~m}$ of the section (Cores 101-627B-55X through 101627B-60X), which are capped with supratidal gypsum, have a minimum rhomb size in lagoonal lithofacies rocks, and that rhomb size increases to a maximum in peritidal lithofacies samples. The reason for this relationship is unclear.

\section{DOLOMITIZATION MECHANISMS}

Regionally extensive dolostones, such as those found in the Mesozoic section of the Bahama Platform and Blake Plateau, usually are explained as the product of diagenesis early in the depositional and burial history of carbonate sediments from active circulation of seawater or seawater-derived fluids (summary by Land, 1985), although the concept of significant late dolomitization in deep-burial environments by basinal fluids was readvanced recently (Mattes and Mountjoy, 1980; Zenger, 1983; Lee and Friedman, 1987). Deep-burial dolomite is characterized petrographically by coarse crystal size and xenotopic texture (Zenger, 1983; Gregg and Sibley, 1984; Gregg, 1985). Land (1985) suggested that much of this deep-burial dolomite is not new to the section but results from stabilization of metastable dolomite formed earlier at shallow-burial depths. In any event, the dolostones penetrated at Site 627 are currently at shallow-burial depths (about $500 \mathrm{mbsf}$ ), and deep-burial diagenetic processes do not apply as the dolomitization mechanism for these rocks. Furthermore, dolomite in the Site 627 section is mostly fine crystalline with idiotopic textures, not coarse crystalline with xenotopic textures, as expected for deep-burial dolomite. 


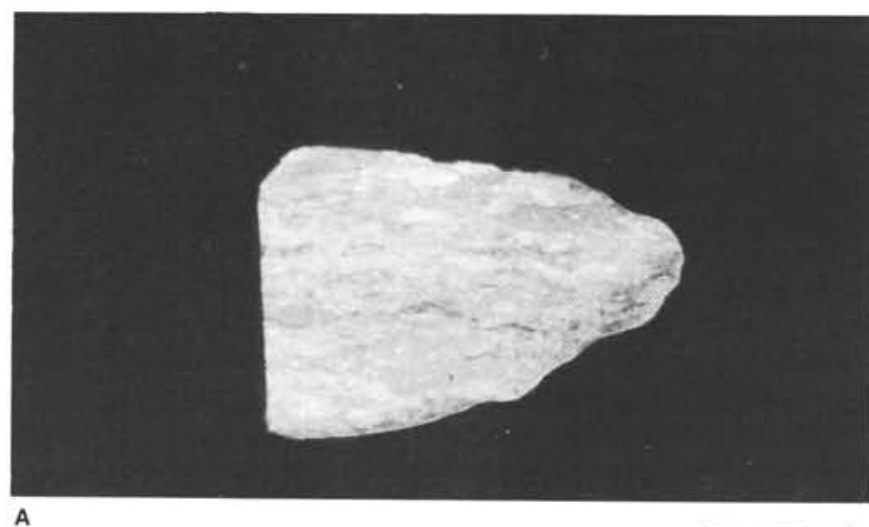

A

$1 \mathrm{~cm}$

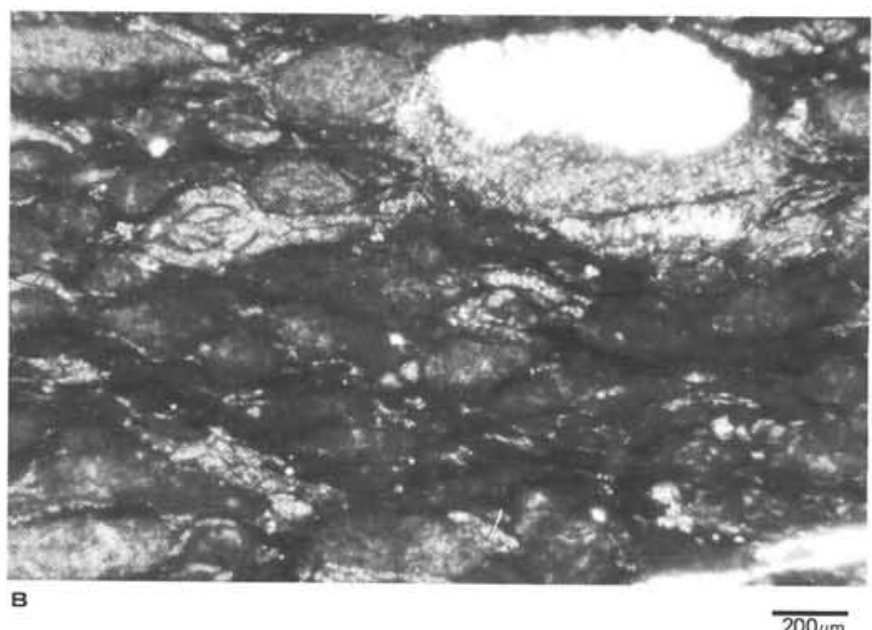

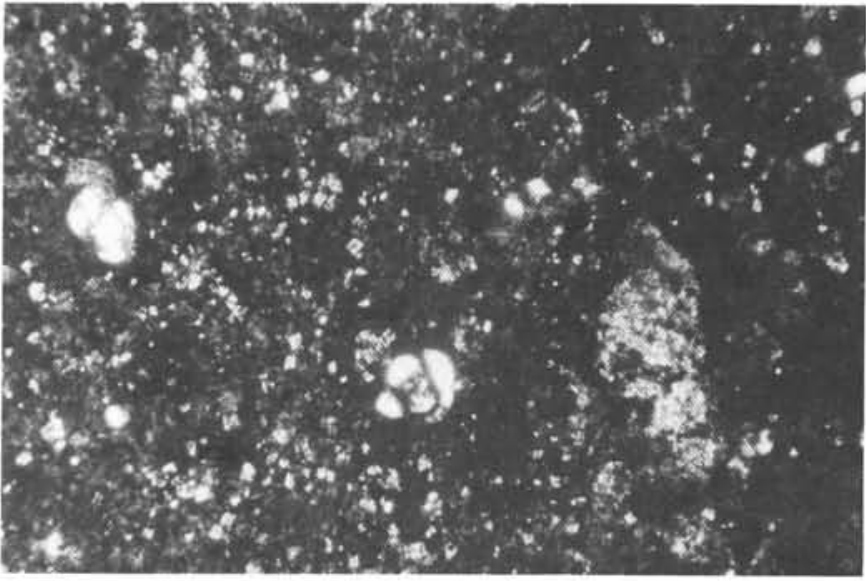

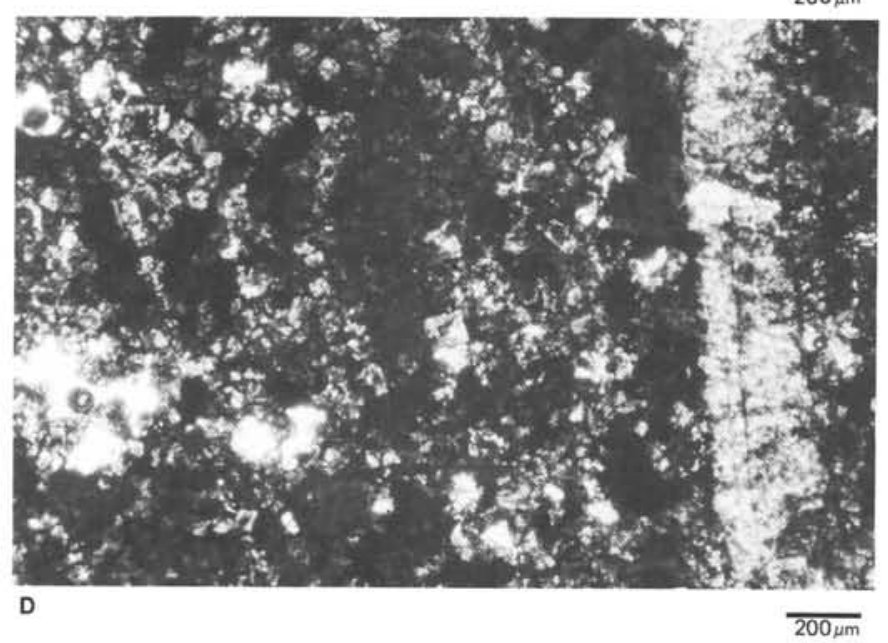

Figure 6. Photograph of thin-section chip (A) and thin-section photomicrographs (B-D) illustrating characteristics of higher energy, less restricted lagoonal lithofacies samples. Thin-section photomicrographs taken with plain light. A. Laminated fossiliferous packstone of Sample 101-627B$57 \mathrm{X}-1,66-68 \mathrm{~cm}$. B. Laminated fossiliferous packstone of Sample 101-627B-57X-1, 66-68 cm, showing oriented skeletal grains, including micritized mollusk grains, miliolid foraminifers, and echinoid grain (upper right), as well as a mold. Note the broken miliolid foraminifers and the close packing of grains. C. Laminated fossiliferous packstone of Sample 101-627B-52X, CC, 5-7 cm, showing micritized skeletal grains and miliolid foraminifers with fine, idiotopic-P dolomite crystals scattered throughout intraparticle porosity. Up is to the right. D. Laminated fossiliferous grainstone of Sample 101-627B-53X-1, 12-14 cm, showing oriented and micritized skeletal grains, including Inoceramus. Fine-to-medium, clear, idiotopic-P dolomite crystals, as well as fine-to-medium, idiotopic-P dolomite crystals with cloudy centers and clear rims, occur mostly in interparticle porosity. Note unfilled molds at left. Up is to the right.

Thus the dolomite occurring at Site 627 probably formed during early diagenesis from hypersaline brines (Deffeyes et al., 1965; Illing et al., 1965; Shinn et al., 1965; McKenzie et al., 1980; Amdurer and Land, 1982; Sims, 1984) or from fluids derived from mixing of marine and meteoric water (Land and Epstein, 1970; Badiozamani, 1973; Folk and Land, 1975). Dolomitization by normal seawater circulating through the platform as part of a convection system driven by geothermal heating (Kohout, 1965, 1967) and tidal pumping (Carballo and Land, 1984) recently was documented (Saller, 1984; Sims, 1984). Geothermal convection systems apparently operate only at platform margins (Sims, 1984), and so probably are not responsible for dolomitization of the Site 627 dolostones, given their location far from the Blake Escarpment.

The association with evaporites, similar to those currently accumulating on the sabkhas of the Persian Gulf (Evans et al., 1969; Kinsman, 1969), in the lower $22 \mathrm{~m}$ of the section (Cores 101-627B-55X through 101-627B-60X), and the occurrence of dolomicrite throughout the late Albian sequence recovered at Site 627 , suggest that hypersaline brines are responsible for much of the dolomite in this section. Association with upwardshoaling sequences capped with peritidal lithofacies strata is also consistent with penecontemporaneous and early diagenetic dolomitization by hypersaline brines. On the other hand, clear, fine, idiotopic dolomite rhombs with cloudy centers and clear rims support dolomitization by mixing zone fluids and by normal seawater pumped by tidal action. As noted previously, to firmly establish the diagenetic history of the carbonate section recovered at Site 627 , geochemical study of these rocks will be necessary.

\section{SUMMARY}

1. Late Albian dolostone, dolomitic limestone, gypsiferous limestone, and gypsiferous dolomitic limestone recovered at Site 627 record deposition principally in lagoons and on tidal flats under low-energy, highly restricted conditions.

2. The section appears to consist of a series of approximately 5-m-thick, upward-shoaling sequences, with lagoonal lithofacies grading upward to peritidal lithofacies. Upward-shoaling sequences are separated by sharp contacts.

3. Dolomite occurs as both dolomicrite and fine, idiotopic crystals. Dolomicrite is confined principally to the upper $28 \mathrm{~m}$ of the section, but fine, idiotopic crystals are distributed through- 

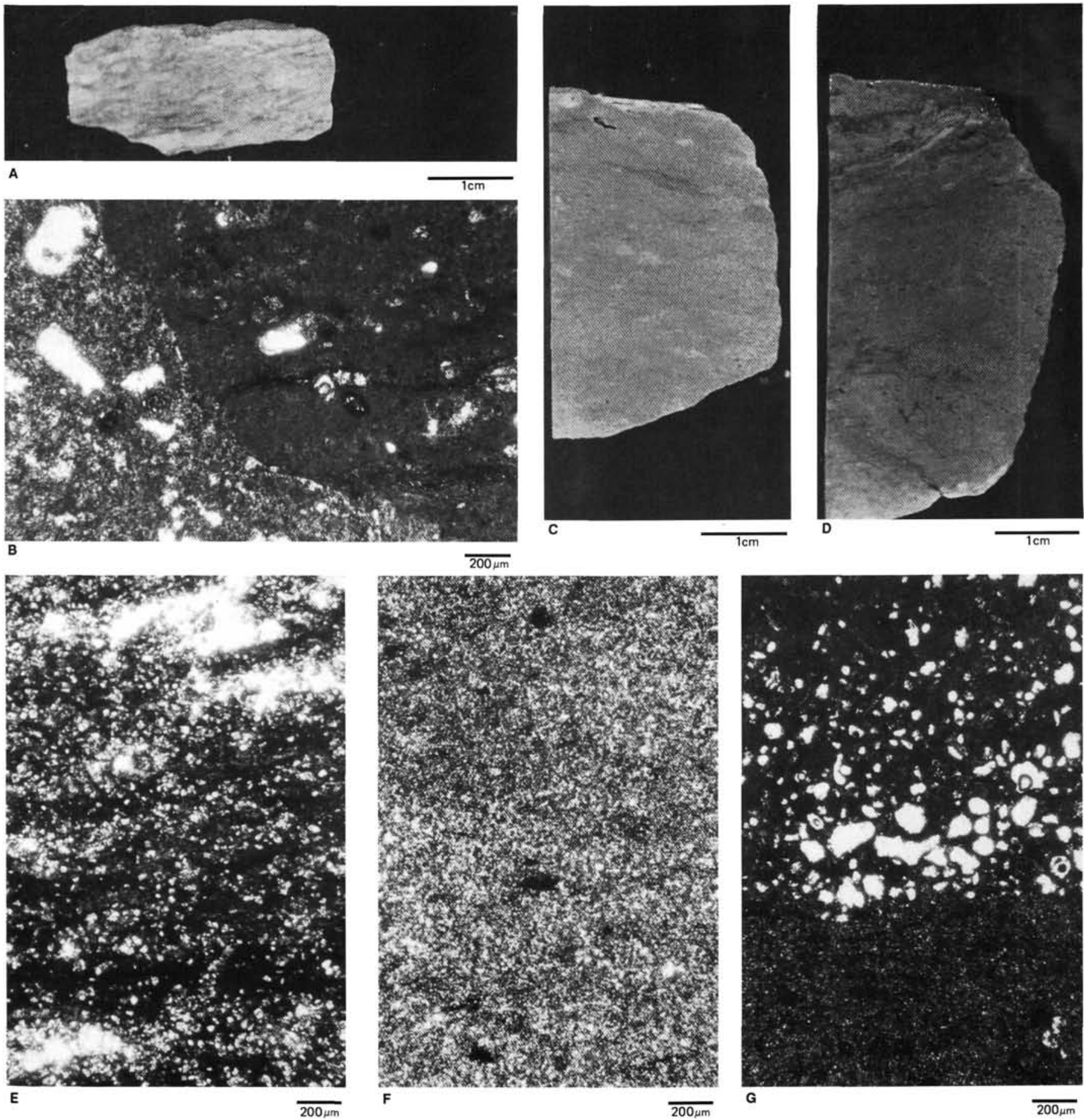

Figure 7. Photographs of thin-section chips (A, C and D) and thin-section photomicrographs (B, E-G) illustrating lamination characteristic of periti$\mathrm{dal}$ and lagoonal lithofacies samples. Thin-section photomicrographs taken with plain light. A. Algal-laminated peritidal dolostone Sample 101627B-51X, CC, 0-3 cm, having mudstone texture and showing slight compaction. B. Edge of teepee structure in algal-laminated peritidal mudstone and wackestone of Sample 101-627B-54X-1, 17-23 cm, showing algal-laminated mudstone and wackestone with molds after miliolid foraminifers (right) and dolomitic wackestone sediment filling void adjacent to teepee. Dolomite rhombs in sediment fill are fine, idiotopic-P crystals. C. Laminated, intraclastic, peritidal dolostone from Sample 101-627B-56X-1, 10-14 cm, having mudstone and wackestone texture and showing compaction effects. D. Laminated (top) and fenestral (bottom) peritidal dolostone of Sample 101-627B-53X-1, 18-23 cm, having mudstone and wackestone texture and showing slight compaction effects. E. Algal-laminated, peritidal dolostone of Sample 101-627B-51X, CC, 0-3 cm, with alternating dolomicrite laminae and laminae rich in fine, idiotopic-E dolomite crystals. Note unfilled moldic or fenestral porosity. F. Lagoonal dolostone of Sample 101-627B-54X-1, 0-6 cm, having slightly laminated appearance because of compaction. Sample consists of an interlocking mass of fine, idiotopic-E dolomite crystals with thick to thin seams of dolomicrite between crystals. Dark blebs about 50-200 $\mu \mathrm{m}$ long may be dead oil. G. Graded molds after miliolid foraminifers and mollusk skeletal grains in lagoonal dolostone intraclast with wackestone and packstone texture of Sample 101-627B$51 \mathrm{X}, \mathrm{CC}, 24-25 \mathrm{~cm}$. Very fine, idiotopic-P dolomite crystals are scattered throughout the dolomicrite matrix of the intraclast (top), which is encased by a lagoonal dolomicrite matrix (bottom) having a greater density of very fine, idiotopic-P dolomite crystals. 


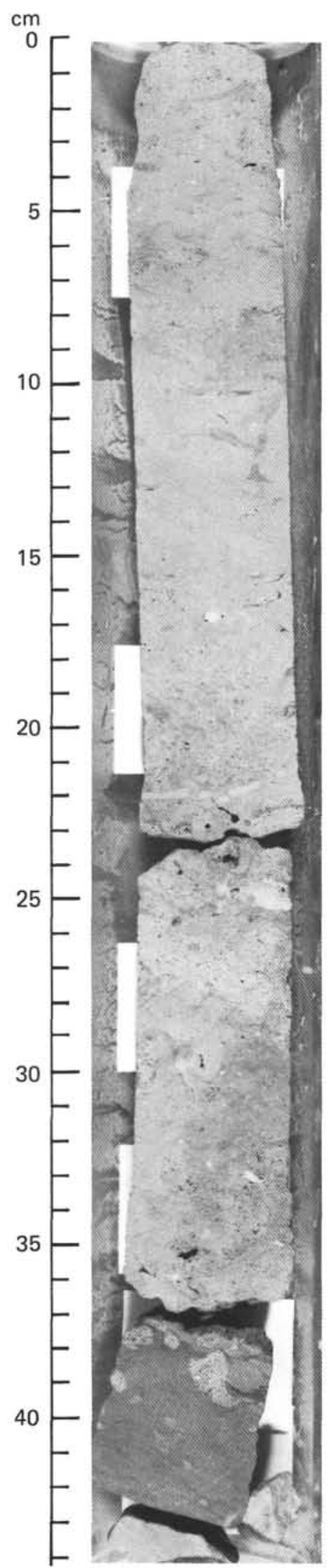

Figure 8. Section 101-627B-54X-1 (506.4-504.8 mbsf) showing the nature of contacts between lagoonal and peritidal lithofacies and the upward-shoaling sequence formed by a lagoonal interval and the overlying peritidal unit, as discussed in the text.
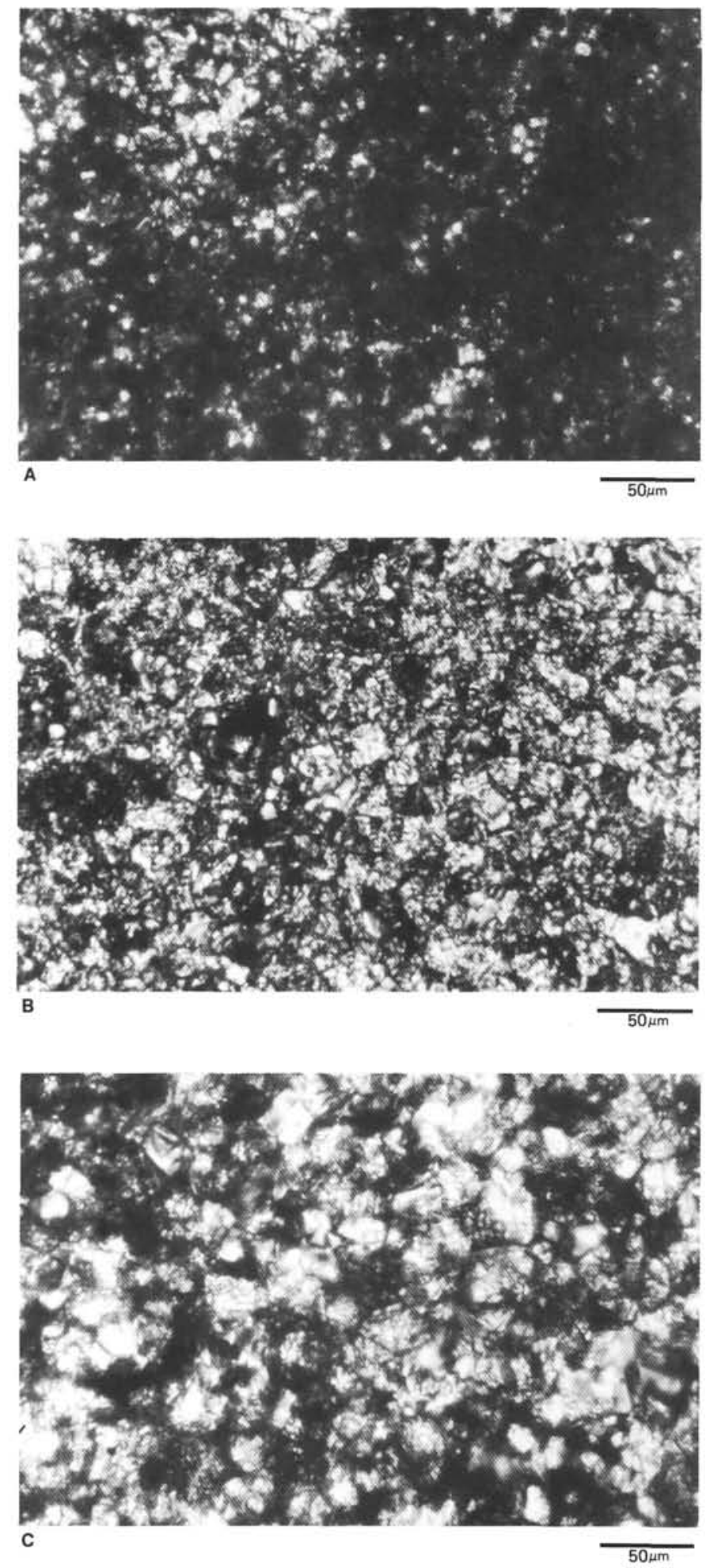

Figure 9. Thin-section photomicrographs (plain light) of characteristic distributions of dolomite rhombs. A. Scattered, very fine and fine, idiotopic-P dolomite crystals in micrite matrix of Sample 101-627B$57 \mathrm{X}-1,7-13 \mathrm{~cm}$. B. Patches of $100 \%$ fine, idiotopic-E dolomite crystals with thin seams of dolomicrite matrix between crystals in dolomicrite matrix of Sample 101-627B-53X-1, 18-23 cm. C. Interlocking matrix of $100 \%$ fine, idiotopic-E dolomite crystals with only thin seams of dolomicrite between crystals in Sample 101-627B-53X, CC, 13-17 cm. 
out. Dolomite rhombs are generally clear or have cloudy centers and clear rims.

4. Dolomitization of this section appears to have occurred during early diagenesis from both hypersaline brines typical of arid sabkhas and fluids derived from mixing of marine and meteoric waters.

\section{ACKNOWLEDGMENTS}

This study was funded by the JOI U.S. Science Advisory Committee through the Texas A\&M University Research Foundation (purchase order 70738, project 1892-A01) to the University of Georgia. I gratefully acknowledge the professionalism of the Master and crew of the JOIDES Resolution (SEDCO/BP 471) and of the ODP scientific and technical staff at sea. The paper was reviewed by J. A. Austin, Jr., H. Chafetz, A. A. Palmer, M. A. Simms, and W. Schlager.

\section{REFERENCES}

Amdurer, M. A., and Land, L. S., 1982. Geochemistry, hydrology, and mineralogy of the sand bulge area, Laguna Madre Flats, south Texas. J. Sediment. Petrol., 52:703-716.

Austin, J. A., Jr., Schlager, W., et al., 1986. Proc. ODP, Init. Repts., 101: College Station, TX (Ocean Drilling Program).

Badiozamani, K., 1973. The Dorag dolomitization model-application to the Middle Ordovician of Wisconsin. J. Sediment. Petrol., 43: 155-161.

Benson, W. E., Sheridan, R. E., et al., 1978. Init. Repts. DSDP, 44: Washington (U.S. Govt. Printing Office).

Bryant, W. R., Meyerhoff, A. A., Brown, N. K., Jr., Furrer, M. A., Pyle, T. E., and Antoine, J. W., 1969. Escarpments, reef trends, and diapiric structures, eastern Gulf of Mexico. AAPG Bull., 53:25062542.

Carballo, J. D., and Land, L. S., 1984. Holocene dolomitization of supratidal sediments by active tidal pumping, Sugarloaf Key, Florida. AAPG Bull., 68:459. (Abstract)

Corso, W., 1983. Sedimentology of rocks dredged from Bahamian Platform slopes [Master's thesis]. Univ. Miami.

Deffeyes, K. S., Lucia, F. J., and Weyl, P. K., 1965. Dolomitization of Recent and Plio-Pleistocene sediments by marine evaporite waters on Bonaire, Netherlands Antilles. In Pray, L. C., and Murray, R. C. (Eds.), Dolomitization and Limestone Diagenesis: Soc. Econ. Paleontol. Mineral. Spec. Publ., 13:71-88.

Enos, P., 1974. Reefs, platforms, and basins of middle Cretaceous in northeast Mexico. AAPG Bull., 58:800-809.

Evans, G., Schmidt, V., Bush, P., and Nelson, H., 1969. Stratigraphy and geologic history of the sabkha, Abu Dhabi, Persian Gulf. Sedimentology, 12:145-159.

Folk, R. L., and Land, L. S., 1975 . Mg/Ca ratio and salinity: two controls over crystallization of dolomite. AAPG Bull., 59:60-68,

Freeman-Lynde, R. P., 1983. Cretaceous and Tertiary samples dredged from the Florida Escarpment, eastern Gulf of Mexico. Trans. Gulf Coast Assoc. Geol. Soc., 33:91-99.

Freeman-Lynde, R. P., Cita, M. B., Jadoul, F., Miller, E. L., and Ryan, W.B.F., 1981. Marine geology of the Bahama Escarpment. Mar. Geol., 44:119-156.

Freeman-Lynde, R. P., and Ryan, W.B.F., 1985. Erosional modification of Bahama Escarpment. Geol. Soc. Am. Bull., 96:481-494.

Goodell, H. G., and Garman, R. K., 1969. Carbonate geochemistry of Superior deep test well, Andros Island, Bahamas: AAPG Bull., 53: 513-536.

Gregg, J. M., 1985. Regional epigenetic dolomitization in the Bonneterre Dolomite (Cambrian), southeastern Missouri. Geology, 13: 503-506.

Gregg, J. M., and Sibley, D. F., 1984. Epigenetic dolomitization and the origin of xenotopic dolomite texture. J. Sediment. Petrol., 54:908931.

Griffith, L. S., Pitcher, M. G., and Rice, G. W., 1969. Quantitative environmental analysis of a Lower Cretaceous reef complex. In Friedman, G. M. (Ed.), Depositional Environments in Carbonate Rocks: Soc. Econ. Paleontol. Mineral. Spec. Publ., 14:120-138.
Heezen, B. C., and Sheridan, R. E., 1966. Lower Cretaceous rocks (Neocomian-Albian) dredged from Blake Escarpment. Science, 154: 1644-1647.

Illing, L. V., Wells, A. J., and Taylor, J.C.M., 1965. Penecontemporary dolomite in the Persian Gulf. In Pray, L. C., and Murray, R. C. (Eds.), Dolomitization and Limestone Diagenesis: Soc. Econ. Paleontol. Mineral. Spec. Publ., 13:89-111.

Khudoley, J. M., 1967. Principal features of Cuban geology. AAPG Bull., 51:668-677.

Kinsman, D.J.J., 1969. Modes of formations, sedimentary associations, and diagnostic features of shallow-water and supratidal evaporites. AAPG Bull., 53:830-840.

Kohout, F. A., 1965. A hypothesis concerning cyclic flow of salt water related to geothermal heating in the Floridan Aquifer. Trans. New York Acad. Sci., ser. 2, 28:249-271.

1967. Groundwater flow and the geothermal regime of the Floridian Plateau. Trans. Gulf Coast Assoc. Geol. Soc., 17:339354.

Land, L. S., 1985. The origin of massive dolomite. J. Geol. Educ., 33: $112-125$.

Land, L. S., and Epstein, S., 1970. Late Pleistocene diagenesis and dolomitization, north Jamaica. Sedimentology, 14:187-200.

Lee, Y. I., and Friedman, G. M., 1987. Deep-burial dolomitization in the Ordovician Ellenburger Group carbonates, west Texas and southeastern New Mexico. J. Sediment. Petrol., 57:544-557.

Mattes, B. W., and Mountjoy, E. W., 1980. Burial dolomitization of the Upper Devonian Miette Buildup, Jasper National Park, Alberta. In Zenger, D. H., Dunham, J. B., and Ethington, R. L. (Eds.), Concepts and Models of Dolomitization: Soc. Econ. Paleontol. Mineral., Spec. Publ., 28:259-297.

McKenzie, J. A., Hsü, K. J., and Schneider, J. F., 1980. Movement of subsurface waters under the sabkha, Abu Dhabi, UAE, and its relation to evaporative dolomite genesis. In Zenger, D. H., Dunham, J. B., and Ethington, R. L. (Eds.), Concepts and Models of Dolomitization: Soc. Econ. Paleontol. Mineral. Spec. Publ., 28:11-30.

Meyerhoff, A. A., and Hatten, C. W., 1974. Bahamas salient of North America. In Burk, C. A., and Drake, C. L. (Eds.), The Geology of Continental Margins: New York (Springer-Verlag), 429-446.

Paull, C. K., and Dillon, W. P., 1980. Erosional origin of the Blake Escarpment: an alternative hypothesis. Geology, 8:538-542.

1981. Reply to "Erosional origin of the Blake Escarpment: an alternative hypothesis." Geology, 9:339-341.

Paulus, F. J., 1972. The geology of Site 98-Northeast Providence Channel. In Hollister, C. D., Ewing, J. I., et al., Init. Repts. DSDP, 11: Washington (U.S. Govt. Printing Office), 877-897.

Saller, A. H., 1984. Petrologic and geochemical constraints on the origin of subsurface dolomite, Enewetak Atoll: an example of dolomitization by normal seawater. Geology, 12:217-220.

Schlager, W., Austin, J. A., Jr., Corso, W., McNulty, C. L., Fluegel, E., Renz, O., and Steinmetz, J. C., 1984. Early Cretaceous platform reentrant and escarpment erosion in the Bahamas. Geology, 12:147150.

Schlager, W., and Ginsburg, R. N., 1981. Bahama carbonate platforms-the deep and the past. Mar. Geol., 44:1-24.

Sheridan, R. E., Berman, R. M., and Corman, D. B., 1971. Faulted limestone block dredged from Blake Escarpment. Geol. Soc. Am. Bull., 82:199-206.

Sheridan, R. E., Crosby, J. T., Bryan, G. M., and Stoffa, P. L., 1981. Stratigraphy and structure of southern Blake Plateau, northern Florida Straits, and northern Bahama Platform from multichannel seismic reflection data. AAPG Bull., 65:2571-2593.

Sheridan, R. E., Smith, J. D., and Gardner, J., 1969. Rock dredges from Blake Escarpment near Great Abaco Canyon. AAPG Bull., 53:2551-2558.

Shinn, E. A., Ginsburg, R. N., and Lloyd, R. M., 1965. Recent supratidal dolomite from Andros Island, Bahamas. In Pray, L. C., and Murray, R. C. (Eds.), Dolomitization and Limestone Diagenesis: Soc. Econ. Paleontol. Mineral. Spec. Publ., 13:112-123.

Sims, M., 1984. Dolomitization by groundwater-flow systems in carbonate platforms. Trans. Gulf Coast Assoc. Geol. Soc., 34:411-420. Spencer, M., 1967. Bahamas deep test. AAPG Bull., 51:263-268. 
Tator, B. A., and Hatfield, L. E., 1975. Bahamas present complex geology. Oil Gas J., 43:172-176; 44:120-122.

Van Buren, H. M., and Mullins, H. T., 1983. Seismic stratigraphy and geologic development of an open-ocean carbonate slope: the northern margin of Little Bahama Bank. In Sheridan, R. E., Gradstein, F. M., et al., Init. Repts. DSDP, 56: Washington (U.S. Govt. Printing Office), 749-762.
Zenger, D. H., 1983. Burial dolomitization in the Lost Burro Formation (Devonian), east-central California, and the significance of late diagenetic dolomitization. Geology, 11:519-522.

Date of initial receipt: 5 January 1987

Date of acceptance: 4 June 1987

Ms 101B-139 